\title{
Thermal summation model and instar determination of all developmental stages of necrophagous beetle, Sciodrepoides watsoni (Spence) (Coleoptera: Leiodidae: Cholevinae)
}

Pavel Jakubec

Necrophagous beetles are underrepresented in forensic entomology studies despite their undeniable utility for the field. In the present article, information is presented regarding the developmental biology and instar determination of Sciodrepoides watsoni (Spence, 1813), a very common species occurring across the Holarctic region. Wild collected beetles were kept in climate chambers at constant temperature $\left(12,15,18,21\right.$ and $\left.28^{\circ} \mathrm{C}\right)$ and their development was documented regularly. Parameters of thermal summation models and standard errors were calculated for each developmental stage. These models may be used for an estimation of post mortem interval in legal investigations after further validation on local populations of $S$. watsoni. An additional methodology is introduced for future studies of size-based characteristics, addressing instar identification bias. The methodology provided estimations (mean, standard error and standard deviation) of $S$. watsoni larval head capsule width for preliminary larval instar determination. The methodology may be used with other morphological features to improve instar determination accuracy. 
1 Thermal summation model and instar determination of all

2 developmental stages of necrophagous beetle, Sciodrepoides watsoni

3 (Spence) (Coleoptera: Leiodidae: Cholevinae)

4 Pavel Jakubec

5 Department of Ecology, Faculty of Environmental Sciences, Czech University of Life Sciences

6 Prague, Kamýcká 129, CZ-165 21 Prague 6 - Suchdol, Czech Republic;

7 e-mail: jakubecp@fzp.czu.cz

\begin{abstract}
Necrophagous beetles are underrepresented in forensic entomology studies despite their undeniable utility for the field. In the present article, information is presented regarding the developmental biology and instar determination of Sciodrepoides watsoni (Spence, 1813), a very common species occurring across the Holarctic region. Wild collected beetles were kept in climate chambers at constant temperature $\left(12,15,18,21\right.$ and $\left.28^{\circ} \mathrm{C}\right)$ and their development was documented regularly. Parameters of thermal summation models and standard errors were calculated for each developmental stage. These models may be used for an estimation of post mortem interval in legal investigations after further validation on local populations of $S$. watsoni. An additional methodology is introduced for future studies of size-based characteristics, addressing instar identification bias. The methodology provided estimations (mean, standard error and standard deviation) of $S$. watsoni larval head capsule width for preliminary larval instar determination. The methodology may be used with other morphological features to improve instar determination accuracy.
\end{abstract}

Forensic entomology is a rapidly developing new field of science (Midgley et al., 2010). New methods and models for estimation of minimum post mortem interval (PMImin) are developing at a very rapid pace (e.g., pre-appearance interval, gene expression during larval development, quantile mixed effects models, generalized additive modeling or generalized additive mixed modeling) (Matuszewski, 2011; Tarone \& Foran, 2011; Baqué et al., 2015a, 2015b), but even the well-established models lack actual data for their further use and application. A good example is the commonly used thermal summation model (Richards \& Villet, 2008). This model, which is based on the assumption that development of immature stages is linear, has been known for several decades (Higley et al., 1986), but it is still not established for the majority of forensically important species of invertebrates, which would be a great contribution to legal investigations. 
33 Currently these models are known for a number of fly species (Diptera) (Nabity et al., 2006;

34 Villet et al., 2006; Richards et al., 2009; Voss et al., 2010a, 2010b, 2014; Tarone et al., 2011;

35 Nassu et al., 2014; Zuha \& Omar, 2014), but only for a few necrobiont beetles.

36 However, using beetles for PMImin estimation has several benefits compared to flies. Beetles

37 tend to have longer development therefore they can be found on and around the carrion for a

38 longer period of time (Villet, 2011). They also do not form a maggot ball like flies, and they can

39 be reared individually so they are easier to handle in laboratory conditions (Midgley et al., 2010).

40 However, probably the best advantage is the possibility of cross validating PMImin estimates

41 between species and groups, such as flies and mites. Cross validating is important mainly in cases

42 when one of these groups or species is affected by external factors (restricted access to body,

43 temperature too high or low, etc.) providing a biased estimate (Šuláková, 2014, pers. comm.).

44 Statistically robust thermal summation models are available only for three species of

45 necrophagous beetles, all belonging to the family Silphidae. These models are for Thanatophilus

46 micans (Fabricius, 1794) (Ridgeway et al., 2014), T. mutilatus (Castelnau, 1840) (Ridgeway et

47 al., 2014) and Oxelytrum discicolle (Brullé, 1840) (Velásquez \& Viloria, 2009). T. micans occurs

48 mainly in Africa and extends to Yemen on the Arabian Peninsula (Schawaller, 1981; Růžička \&

49 Schneider, 2004), T. mutilatus has a geographical distribution restricted to the South Africa region

50 (Schawaller, 1981, 1987) and O. discicolle inhabits Central and South America (Peck \&

51 Anderson, 1985). Therefore, North America, Europe and most of Asia lack a single beetle species

52 with a thermal summation model.

53 Models alone are not sufficient for species to be useful in legal investigations. There are other

54 criteria to be fulfilled. Any forensic entomologist has to be able to identify those species in every

55 stage of development and discriminate between larval instars. Without reliable instar

56 determination, it is not possible to expect reliable PMImin estimates. However, this is sometimes

57 complicated, because beetle larvae often lack morphological characteristics specific to particular

58 instars, which would allow such identification (Velásquez \& Viloria, 2009). In such cases the

59 body size frequency distributions are commonly used (see Logan et al., 1998).

60 Not all size-based characteristics are equally appropriate for instar determination. Dyar (1890)

61 observed that head width is a very advantageous characteristic for larval instar determination. He

62 supported his claim by showing that head width stays the same across intermoult intervals and

63 also that for some lepidopteran larvae it follows a geometrical progression. These properties

64 enable estimation of number of instars even from incomplete developmental information, when

65 some instars were unobserved and are widely used for instar determination (e.g. Delbac,

66 Lecharpentier \& Thiery, 2010; Wu, Wang \& Wu, 2012a,b; Gomez et al., 2015).

67 Head width or mean head width can be found for many species in their published descriptions

68 together with other morphological and size based characteristics. Unfortunately these

69 measurements are often based on a small number of animals, because they are not intended as

70 statistically robust models, thusthe true mean value could be very different from the reported one.

71 This bias is a serious problem for instar determination in applied disciplines like forensic 
72 entomology, especially when we are dealing with animals from spatially or temporally distant

73 populations (Stillwell \& Fox, 2009). For several species of necrobiont beetles statistically robust

74 models were developed, based on measuring not only head width, but also other size based

75 characteristics (Midgley \& Villet, 2009b, Velásquez \& Viloria, 2010 and Fratczak \&

76 Matuszewski, 2014). However, these models are available only for two European species, namely

77 Necrodes littoralis (Linnaeus, 1758) (Silphidae) and Creophilus maxillosus (Linnaeus, 1758)

78 (Staphylinidae) (Fratczak \& Matuszewski, 2014) and even those models should be used with

79 great care as I will discuss later in the text.

80

81

82
Sciodrepoides watsoni (Spence, 1813) is one of the most widespread and abundant species of necrophagous beetles in the Holarctic region (Peck \& Cook, 2002; Perreau, 2004). Robust occurrence data are available especially for Europe (Fig. 1). This saprophagous beetle belongs to subfamily Cholevinae (Leiodidae) and is rather inconspicuous, because the whole body is brown and about 3 millimeters long (Szymczakowski, 1961; Perreau, 2004) (see Fig. 2). Adults can be fairly easily distinguished from the other European species of genus Sciodrepoides by the shape of the antennal segments (Szymczakowski, 1961). The main peak of activity is during the warmer parts of the year (late spring and summer) (Růžička, 1994). All stages can be found on decaying corpses of vertebrates in various types of habitats where they feed and develop (Růžička, 1994; Peck \& Cook, 2002; Topp, 2003).

Egg, all larval instars and pupae of $S$. watsoni were described recently by Kilian \& Mądra (2015), and also a DNA barcode for validation is available (Schilthuizen et al., 2011). Therefore identification of this species in every stage of development is not an issue. Instar determination of S. watsoni larvae is also possible (Kilian \& Mądra, 2015), but its natural variability was not covered in the case of size based characteristics.

This study attempts to improve the utility of $S$. watsoni for PMImin estimation by calculating the parameters of thermal summation models for each stage (egg, three larval instars and pupae) and developing an additional characteristic for instar determination, based on photographic documentation and measurement of larval head capsule width. The latter methodology may be developed to cover natural variability and can be easily observed, measured, and evaluated. Combined with a morphological feature unique to specific instars, these data provide accurate identification of larval instar and may be integrated into PMImin estimation models.

\section{Material and Methods}

A laboratory colony was started with adults of S. watsoni, which were collected in spring of 2012 and/or 2013 from five localities in the Czech Republic (Prague - Suchdol (15 May - 12 April 2012, 15 May - 12 April 2013), Běstvina (7 - 11 April 2012, 6 - 10 April 2013), Domažlice (28 May - 12 April 2013) and Klatovy (14 - 28 May 2013)).

Beetles were collected using 10 baited pitfall traps, placed at each locality. The traps were composed of 1,080 $\mathrm{ml}$ plastic buckets (opening of $103 \mathrm{~mm}$ and $117 \mathrm{~mm}$ deep). These buckets were embedded in substrate up to the rim to eliminate any obstructions which could deter beetles from entering. As protection against rain metal roofs $(150 \times 150 \mathrm{~mm})$ were put over the traps. The 
111 roof was supported by four $100 \mathrm{~mm}$ nails, one in each corner, and placed approximately two 112 centimeters above the surface. The bait, ripened cheese $\left(\right.$ Romadur $\left.^{\mathbb{B}}\right)$ and fish meat $($ Scomber 113 scombrus Linnaeus, 1758), was placed directly inside the bucket on a shallow layer of moist soil.

114 This created good conditions for survival of the trapped beetles between servicing, which was 115 usually done once a week.

116 After transport to the laboratory, beetles were identified and sexed under a binocular microscope 117 (Olympus SZX7). Most of the beetles were randomly assigned to form breeding groups of at least 118 four individuals ( 2 males and 2 females). Specimens from the same locality were kept together 119 regardless of capture date to eliminate cross-breeding of different populations. These groups were 120 formed to produce new progeny, which were observed throughout their development (breeding 121 experiment).

122 Groups were kept in Petri dishes with a layer of soil and small piece (approx. 5x5 mm) of fish 123 meat (Scomber scombrus) as a food source. The content of the dish was lightly sprayed with tap 124 water every day and food was provided ad libitum and changed to prevent fungal growth.

125 Dishes were randomly placed in one of six climate chambers (custom made by CIRIS s.r.o.). The 126 chambers were set up at constant temperature $\left(12,15,18,21,25\right.$ or $\left.28^{\circ} \mathrm{C}\right)$ and 16 hours of light 127 and 8 hours of dark photoperiod regime, maintained by fluorescent light (Osram L 8W/640). A 128 similar number of breeding groups from the same locality were placed in each chamber for 129 beetles from Praha and Běstvina. However, because few adults were obtained from Domažlice 130 and Klatovy, this was not possible, and they were kept together in one treatment $\left(18^{\circ} \mathrm{C}\right)$.

131 An observation study of their natural behavior was also conducted in a small plastic box (15x6x2 132 centimeters) with 12 adult individuals ( 7 females and 5 males) from the Prague population. In 133 this colony, larvae were not separated from adults or each other, but were allowed to interact 134 freely and without intervention (measuring, photographing or other manipulations). The box itself 135 was placed in an $18^{\circ} \mathrm{C}$ treatment, and its inhabitants were attended in the same way as the 136 specimens in the breeding experiment (regular water spray and meat replaced to prevent fungal 137 growth).

138 In the breeding experiment, the method of handling eggs and first instar was changed slightly 139 between the years to improve the accuracy of observations. During the first year of experiment 140 (2012), dishes were searched for eggs which were transferred individually to a separate dish.

141 However, it was difficult to locate eggs of $S$. watsoni as they were very small and adults tended to 142 hide them in the substrate. Therefore, the estimation of egg and L1 development for the first year 143 was inconsistent and was not used in the models. In the second year (2013), the entire breeding 144 group was transferred to a new Petri dish every day. The old dishes were marked and kept in the 145 same climate chamber as the parents. Dishes were checked every day for emergence of the first 146 instar larvae that were further separated into their own dishes so that individual development 147 could be observed. The time when the eggs were laid was estimated as a half-time between the 148 transfers of the breeding group. 
149 Larvae from the second year (2013) breeding experiment were photographed every day, starting with their occurrence as the first instar larvae until pupation. In this way, morphological changes were continuously documented during their development. To do this, the Petri dish was removed from the climate chamber and was placed under the stereoscopic microscope to locate the larva, which tended to stay near the food source. The larva was transferred with a fine brush to a white sheet of paper and photographed (microscope Nikon SMZ-2T with attached camera Sony with resolution of $768 \times 576$ pixels). Once a usable picture was obtained, the larva was returned to Petri dish and back to the corresponding climate chamber. The whole process of finding the larva and taking a picture did not usually take more than $1 \mathrm{~min}$. Key developmental stages of each larva, with the accurate date and time, could be distinguished based on photographs simply by keeping track of the change in the width of their head capsule, because the width expanded after each molt. Increase in the width over $0.1 \mathrm{~mm}$ was considered as a clear sign of the molt. This strategy was very useful for data collection, because exuvia were not needed for confirmation of molt to the next instar.

Because the dorsal side of larvae was photographed daily, many characteristics were monitored. However, the thorax and abdomen of the $S$. watsoni larvae are not strongly sclerotized (Fig. 3) and were thus omitted for instar determination, as well as the body length, which has too much variation. Measuring of some smaller parts, such as urogomphi or antennae, proved impractical, because it was very challenging to measure them accurately on a living and moving animal. Chilling or $\mathrm{CO}_{2}$ immobilization could not be used, because it would stress the specimens even more and it could potentially affect the length of development.

The most stable and reliable feature for the instar determination of $S$. watsoni larvae was the head capsule. This part of the body was strongly sclerotized, therefore it was not affected by water or food content, but it changes in size after each molt so it is tightly linked with individual growth. Also, the head does not change its size in different fixation media, or even after desiccation, thus the instar can be identified even for very poorly handled and long dead specimens. Ultimately, the head capsule width was chosen over its length for a practical reason. Head width of living larvae did not change on the pictures captured from above, but length varied considerably.

For estimating the mean and standard deviation of the head capsule width (measured in the widest point, see Fig. 3), I used all photographs where the head was clearly visible and was sharp enough to make a precise measurement. All measurements were with graphical program EidosMicro, calibrated by a precise ruler.

Parameters of thermal summation model (lower developmental threshold $(\mathrm{t})$ and sum of effective temperatures $(\mathrm{k})$ ) were estimated for each developmental stage using the major axis regression method $((\mathrm{DT})=\mathrm{k}+\mathrm{tD})$, where $\mathrm{D}$ is duration of development, and $\mathrm{T}$ is environmental temperature $\left({ }^{\circ} \mathrm{C}\right)$. This formula was developed previously (Ikemoto \& Takai, 2000) and is commonly used for estimation of thermal summation parameters and their standard errors in forensic entomology (e.g., Midgley \& Villet, 2009a; Ridgeway et al., 2014). The method is based on a standard linearized formula $(1 / \mathrm{D}=-(\mathrm{t} / \mathrm{k})+(1 / \mathrm{k}) \mathrm{T})$, but it weights out the data points in lower and upper part of the temperature range to obtain more reliable estimates of the parameters. 
189 Normality of all the data was confirmed by evaluation of the qqplots and histograms. The

190 significance level was set at 5\%. Data management and all analysis were carried out using R

191 statistical program (R Core Team, 2015). Graphical outputs were handled by ggplot2 and ggmap

192 R packages (Wickham, 2009; Kahle \& Wickham, 2013).

\section{Results}

In total, 81 adult specimens of S. watsoni were collected (Prague - 174, Běstvina - 178, Klatovy 19, Domažlice - 28), and they produced 399 first instar larvae for the breeding experiment.

Because only twelve adults were obtained from Klatovy and six from Domažlice, it was impossible to split them between temperature treatments, and they all were reared at $18^{\circ} \mathrm{C}$.

198 In the breeding experiment, the duration of development of all $S$. watsoni stages was recorded, namely egg, three larval instars (L1, L2 and L3) and pupae. These observations were made on 399 specimens in total, starting with the first instar larvae.

Higher temperatures $\left(25\right.$ and $\left.28^{\circ} \mathrm{C}\right)$ were probably limiting to breeding activity of the beetles in the experiment. Ultimately I did not obtain any larvae from the $28^{\circ} \mathrm{C}$ treatment. Mortality in the other treatments was also quite high, especially for the third instar and pupae (see Fig. 4) and only 23 individuals developed until adulthood. Low temperature also prevented breeding, as I did not observe any larvae in the $12^{\circ} \mathrm{C}$ treatment.

The development times differed between stages (Fig. 5) and the mean development time decreased with increasing temperature (Fig. 6), except for L2 and L3 instars in the $25^{\circ} \mathrm{C}$ treatment. The sum of effective temperatures $(\mathrm{k})$ and lower developmental threshold $(\mathrm{t})$ values were calculated for all developmental stages of $S$. watsoni with expected errors (Table 1 and Fig. 7).

Mortality of the specimens in the observation study could not be measured, but the colony itself prospered very well and number of adults increased steadily, which is in contrast with what I observed in the breeding experiment. Females tended to hide their eggs in small holes or crevices in the substrate. Newly hatched larvae could be found mostly around the food source. The third instar larvae, after few days of feeding, dug underground and created small chambers where they pupated. No cannibalism or hostility of any kind between individuals was recorded.

217 For the instar determination measurements, I made 2,104 photographs, but only 1,731 were good 218 enough to allow precise measurements of the head width. Those pictures covered all three larval instars ( $\mathrm{L} 1=591, \mathrm{~L} 2=500$ and L3 $=640$ pictures). The bias in the number of pictures between

220 different stages was caused by the difference in the duration of development of these instars (lower stages of development are shorter in duration), and it was also much more challenging to take a usable picture of the first or second instar larvae. 
226 values on the both sides of the spectrum, but those were very rare. If head capsule measurement is used along with morphological characters like chaetotaxy and brown spot on the head, as described by Kilian \& Madra (2015), the accuracy and precision of larval instar determination of S. watsoni may be improved.

No larvae were obtained from the 28 and $12^{\circ} \mathrm{C}$ treatment, probably because adults did not oviposit at this temperature or egg mortality was too high. The second claim is supported by the fact that no eggs were found. However, as mentioned in the methodology section, eggs of $S$. watsoni are tiny and may be overlooked, especially if there were only a few.

Mortality of the specimens in the breeding experiment was very high over all treatments especially in the third instar. High mortality in this stage is not uncommon, but in this case it was in sharp contrast with what was found in the observation study. The entire colony in the observation study prospered and even increased in the number of adults over time. The only difference between these two studies was that individuals were not separated and photographed in the observation study.

Despite the increased mortality of some stages in the breeding experiment, the total length of development (from egg until adulthood) did not differ significantly from values in the observation study (ca. 28 days at $18^{\circ} \mathrm{C}$ ) and also those reported by Kilian \& Mądra (2015) (ca. 20 days at $20^{\circ} \mathrm{C}$ ). Therefore larvae in the breeding experiment likely did not prolong development due to unfavorable conditions. Larvae also did not increase or decrease number of their instars, and they had to undergo three larval instars before maturation, which was also reported by Kilian \& Mądra (2015). Aggression or hostility was not observed between specimens, nor was there cannibalism as has previously been reported for this species (Kilian \& Mądra, 2015). However, it was possible that it was missed due to the large number of larvae and adults in a box, close to one hundred. The photographing process was not so intrusive to be responsible for high mortality rates, and thus it is more likely that separation from other larvae and adults was probably the reason for the increased mortality. Peck (1975) mentioned that the cave adapted beetle Ptomaphagus hirtus (Tellkampf, 1844) (Leiodidae: Cholevinae: Ptomaphagini) needed soil from its cave of origin to successfully complete development. Soil bacteria probably played some part in this process, because specimens did not develop on autoclaved soil. In the experiments, it is possible that adults feeding along with larvae could have provided such bacteria. Another explanation could be that feeding of multiple individuals is much more effective or improves the quality of the food source. As a support for this hypothesis, I observed a very rapid growth of some fungi in Petri dishes with a single larva, but almost none in the observational study containers where a large number of individuals were feeding.

The methodology of egg extraction was changed in the second year because eggs were easily overlooked in the substrate, and beetles refused to lay their eggs in offered damp cotton wool balls or small pieces of paper. To prevent bias in recorded time, a dish rotation methodology was 
264 introduced, and adults stayed in the same dish only one day and then were moved to another.

265 Those used dishes were then regularly searched for emerging larvae. The main issue with this

266 approach (dish rotation) is that egg mortality could not be determined.

267 The mean development time decreased with increasing temperature (Fig. 6), except for L2 and

$268 \mathrm{~L} 3$ instars in the $25^{\circ} \mathrm{C}$ treatment. Therefore, the optimal temperature of $S$. watsoni $\mathrm{L} 2$ and L3

269 instars may be between $21^{\circ} \mathrm{C}$ and $25^{\circ} \mathrm{C}$ (e.g., temperature with highest developmental rate where

270 the specimen is still able to reach maturity). Optimal temperatures for lower stages may be

271 higher, which agrees with the findings of Engler (1981), who reported $S$. watsoni as a warm

272 season species in contrast to some species of Choleva and Catops that prefer to breed during the

273 winter season, and their optimal temperatures for development were below $16^{\circ} \mathrm{C}$ (e.g., Catops

274 nigricans, Choleva agilis and Ch. elongata). This hypothesis also agrees with the findings of

275 Ridgeway et al. (2014) who reported that the optimal temperature for Afrotropic Thanatophilus

276 mutilatus is between $14-25^{\circ} \mathrm{C}$.

277 Measuring development time for pupae was even more challenging due to the fact that they did

278 not pupate close to the wall of the Petri dish. Searching for them was sometimes unsuccessful,

279 and some specimens surprised us when they reappeared as adults, because they had been

280 recorded as missing and presumed dead.

281 The methodology of measuring the size of the instars was based on continual observation of

282 separated individuals, from egg until pupation, so stage-specific information was available

283 regardless of their size. This approach differs from other studies with similar goals (Velásquez \&

284 Viloria, 2010; Fratczak \& Matuszewski, 2014), where authors tried to estimate the stage of

285 development based on the size of selected characteristics without prior knowledge of the true

286 stage of the specimen. The latter approach can be problematic, because measured characteristics

287 are correlated, and therefore larger larvae could be misidentified as a later instar. This bias would

288 probably not affect the obtained mean values, but it would give a distorted picture of variation

289 and ultimately give false confidence in determinations. This approach could be corrected if

290 information about the risk of erroneous determination would be calculated beforehand (see

291 Merville et al., 2014).

292 The data demonstrated that instars have some overlap in the head widths, especially true for the

293 first and second instar. In these regions the uncertainty of determination based solely on the head

294 width is very high, so the use of some additional morphological characteristics is in place. A first

295 instar larva has only primary setae on its body and the head is without any colored spots, but after

296 molting to the second instar, a secondary set of setae will emerge and a brown spot will appear on

297 the head (light brown and not fully defined) (Kilian \& Mądra, 2015). Setae are also present

298 without any change on the third instar larvae, but the brown spot is much darker with sharp and

299 well defined edge (Kilian \& Mądra, 2015). Thus chaetotaxy and pigmentation of the head can be

300 used for the discrimination of all instars. The data provide developmental parameters for $S$.

301 watsoni together with a new and reliable characteristic for instar determination. This species is so

302 far the smallest necrophagous beetle with a known thermal summation model. The developmental

303 characteristics provided in this study will help to more accurately estimate the PMImin. 
305 I would like to thank A. Honěk and P. Saska for sharing their insight about beetle development

306 and construction of thermal summation models. I am also grateful to Jan Růžička and Max

307 Barclay who provided many valuable comment and language corrections. This research would

308 not have been possible without the help of my students from the Czech University of Life

309 Sciences Prague: T. Račáková, J. Pšajdl and M. Slachová, who took care of the experiment at

310 times I could not.

\section{References}

312 BAqué, M., AMEndt, J., Verhoff, M.A. \& ZEHner, R. 2015a: Descriptive analyses of

313 differentially expressed genes during larval development of Calliphora vicina (Diptera:

314 Calliphoridae). International Journal of Legal Medicine, 129, 891-902.

315 Baqué, M., Filmann, N., Verhoff, M.A. \& AMEndt, J. 2015b: Establishment of

316 developmental charts for the larvae of the blow fly Calliphora vicina using quantile regression.

317 Forensic Science International, 248, 1-9.

318 Delbac L, LeChARPENTIER P, ThIERY D. 2010. Larval instars determination for the European

319 Grapevine Moth (Lepidoptera: Tortricidae) based on the frequency distribution of head-capsule

320 widths. Crop Protection 29:623-630. DOI: 10.1016/j.cropro.2010.01.009.DYAR, H.G. 1890: The

321 Number of Molts of Lepidopterous Larvae. Psyche: A Journal of Entomology, 5, 420-422.

322 ENGLER, I. 1981: Vergleichende Untersuchungen zur jahreszeitlichen Einpassung von Catopiden 323 (Col.) in ihren Lebensraum. Zoologische Jahrbücher. Abteilung für Systematik, Geographie und 324 Biologie der Tiere, 109, 399-432.

325 FRATCZAK, K. \& MATUSZEWSKI, S. 2014: Instar determination in forensically useful beetles

326 Necrodes littoralis (Silphidae) and Creophilus maxillosus (Staphylinidae). Forensic Science

327 International, 241, 20-26.

328 GBIF. 2015: Sciodrepoides watsoni [WWW Document]. URL

329 http://www.gbif.org/species/4445042 [accessed on 2015].

330 Gomez J, Chavez BY, Castillo A, Valle FJ, Vega FE. 2015. The Coffee Berry Borer

331 (Coleoptera: Curculionidae): How Many Instars are There? Annals of the Entomological Society

332 of America 108:311-315. DOI: 10.1093/aesa/sav009.Higley, L.G., PedigO, L.P. \& OstLIE, K.R.

333 1986: Degday: A Program for Calculating Degree-days, and Assumptions Behind the Degree-day

334 Approach. Environmental Entomology, 15, 999-1016.

335 IKemoto, T. \& TAKAI, K. 2000: A New Linearized Formula for the Law of Total Effective

336 Temperature and the Evaluation of Line-Fitting Methods with Both Variables Subject to Error.

337 Environmental Entomology, 29, 671-682. 
338 KAHLE, D. \& WiCKHAM, H. 2013: ggmap : Spatial Visualization with. The R Journal, 5, 144339161.

340 Kilian, A. \& MĄDRA, A. 2015: Comments on the biology of Sciodrepoides watsoni watsoni 341 (Spence, 1813) with descriptions of larvae and pupa (Coleoptera: Leiodidae: Cholevinae).

342 Zootaxa, 3955, 45-61.

343 Logan J.A., Bentz B.J., VANDYGRIFF J.C. \& TURNER D.L. 1998: General program for 344 determining instar distributions from headcapsule widths: Example analysis of mountain pine 345 beetle (Coleoptera: Scolytidae) data. Environmental Entomology, 27, 555-563.

346 MATUSZEWSKI, S. 2011: Estimating the pre-appearance interval from temperature in Necrodes 347 littoralis L. (Coleoptera: Silphidae). Forensic Science International, 212, 180-188.

Merville A., Vallier A., Venner S., Siberchicot A., Fouchet D., Heddi A., Bel-Venner M.C. 2014. Determining the instar of a weevil larva (Coleoptera: Curculionidae) using a parsimonious method. European Journal of Entomology 111:567-573.

Midgley, J.M., Richards, C.S. \& Villet, M.H. 2010: The Utility of Coleoptera in Forensic Investigations. In Current Concepts in Forensic Entomology (ed. by Amendt, J., Goff, M.L., Campobasso, C.P. \& Grassberger, M.). Springer Netherlands, Dordrecht, pp. 57-68. (Coleoptera: Silphidae) at constant temperatures. International Journal of Legal Medicine, 123, 285-292.

Midgley, J.M. \& Villet, M.H. 2009b: Effect of the killing method on post-mortem change in length of larvae of Thanatophilus micans (Fabricius 1794) (Coleoptera: Silphidae) stored in 70\% ethanol. International Journal of Legal Medicine, 123, 103-8.

NABity, P.D., Higley, L.G. \& Heng-Moss, T.M. 2006: Effects of temperature on development of Phormia regina (Diptera: Calliphoridae) and use of developmental data in determining time intervals in forensic entomology. Journal of Medical Entomology, 43, 1276-86.

NAssu, M.P., Thyssen, P.J. \& Linhares, A.X. 2014: Developmental rate of immatures of two

364 fly species of forensic importance: Sarcophaga (Liopygia) ruficornis and Microcerella halli 365 (Diptera: Sarcophagidae). Parasitology Research, 113, 217-22.

366 PeCK, S. 1975: The life cycle of a Kentucky cave beetle, Ptomaphagus hirtus, (Coleoptera; 367 Leiodidae; Catopinae). International Journal of Speleology, 7, 7-17.

368 PeCK, S. \& ANDERSON, R. 1985: Taxonomy, phylogeny and biogeography of the carrion beetles 369 of Latin America (Coleoptera: Silphidae). Quaestiones Entomologicae, 21, 247-317. 
370 PECK, S.B. \& COOK, J. 2002: Systematics, distributions, and bionomics of the small carrion 371 beetles (Coleoptera: Leiodidae: Cholevinae: Cholevini) of North America. The Canadian 372 Entomologist, 134, 723-787.

373 Perreau, M. 2004: Family Leiodidae Fleming, 1821. In Catalogue of Palaearctic Coleoptera 374 Hydrophiloidea Histeroidea Staphylinoidea (ed. by Löbl, I. \& Smetana, A.). Apollo Books, 375 Steensrup, pp. 133-203.

376 R Core TEAm. 2015: R: A Language and Environmnet for Statistical Computing.

377 Ridgeway, J. A., Midgley, J.M., Collett, I.J. \& Villet, M.H. 2014: Advantages of using 378 development models of the carrion beetles Thanatophilus micans (Fabricius) and T. mutilatus 379 (Castelneau) (Coleoptera: Silphidae) for estimating minimum post mortem intervals, verified 380 with case data. International Journal of Legal Medicine, 128, 207-220.

381 Richards, C.S., Crous, K.L. \& Villet, M.H. 2009: Models of development for blowfly sister 382 species Chrysomya chloropyga and Chrysomya putoria. Medical and Veterinary Entomology, 23, $38356-61$.

384 RiCHARDS, C.S. \& VILLET, M.H. 2008: Factors affecting accuracy and precision of thermal 385 summation models of insect development used to estimate post-mortem intervals. International 386 Journal of Legal Medicine, 122, 401-408.

387 RŮŽIČKA, J. 1994: Seasonal activity and habitat associations of Silphidae and Leiodidae: 388 Cholevinae (Coleoptera) in central Bohemia. Acta Societatis Zoologicae Bohemoslovicae.

389 RŮŽIČKA, J. \& SCHNEIDER, J. 2004: Family Silphidae Latreille, 1807. In Catalogue of

390 Palaearctic Coleoptera, Vol. 2: Hydrophiloidea - Histeroidea - Staphylinoidea (ed. by Löbl, I. \& 391 Smetana, A.). Apollo Books, Steenstrup, pp. 229-237.

392 Schawaller, W. 1981: Taxonomie und Faunistik der Gattung Thanatophilus (Coleoptera:

393 Silphidae). Stutgarter Beiträge zur Naturkunde, Serie A (Biologie), 351, 1-21.

394 SCHAWALlER, W. 1987: Faunistische und systematische Daten zur Silphidae-Fauna Südafrikas 395 (Coleoptera: Silphidae). Entomofauna, 8, 277-285.

396 Schilthuizen, M., Scholte, C., Wijk, R.E.J. VAn, DOMmershuiJzen, J., Horst, D. VAN DER, 397 ZU SChlochtern, M.M., LIEVERS, R., GroenenBERG, D.S.J. 2011: Using DNA-barcoding to 398 make the necrobiont beetle family Cholevidae accessible for forensic entomology. Forensic 399 Science International, 210, 91-95.

400 Stillwell, R.C. \& Fox, C.W. 2009: Geographic variation in body size, sexual size dimorphism 401 and fitness components of a seed beetle: Local adaptation versus phenotypic plasticity. Oikos, 402 118, 703-712. 
403 SzYmCZAKOwSKI, W. 1961: Klucze do oznaczania owadów Polski, Czesść XIX Chrzqszcze 404 Coleoptera, Zeszyt 13 Catopidae. [Keys to identification of Poland insects, Part XIX Beetles 405 Coleoptera, Issue 13 Small carrion beetles - Catopidae)]. Państwowe Wydawnictvo Naukowe, 406 Warszawa.

407 TARONE, A.M. \& Foran, D.R. 2011: Gene expression during blow fly development: improving 408 the precision of age estimates in forensic entomology. Journal of Forensic Sciences, 56, S112-22.

409 Tarone, A.M., PiCard, C.J., Spiegelman, C. \& Foran, D.R. 2011: Population and Temperature 410 Effects on Lucilia sericata (Diptera: Calliphoridae) Body Size and Minimum Development Time. 411 Journal of Medical Entomology, 48, 1062-1068.

412 TOPP, W. 2003: Phenotypic plasticity and development of cold-season insects (Coleoptera: 413 Leiodidae) and their response to climatic change. European Journal of Entomology, 100, 233414243.

415 Velásquez, Y. \& Viloria, A.L. 2009: Effects of temperature on the development of the 416 Neotropical carrion beetle Oxelytrum discicolle (Brullé, 1840) (Coleoptera: Silphidae). Forensic 417 Science International, 185, 107-109.

418 VelÁsQUeZ, Y. \& VILORIA, A.L. 2010: Instar determination of the neotropical beetle Oxelytrum 419 discicolle (Coleoptera: Silphidae). Journal of Medical Entomology, 47, 723-726.

420 VILLET, M. 2011: African carrion ecosystems and their insect communities in relation to forensic 421 entomology. Pest Technology, 5, 1-15.

422 Villet, M.H., MacKenZIE, B. \& Muller, W.J. 2006: Larval development of the carrion423 breeding flesh fly, Sarcophaga (Liosarcophaga) tibialis Macquart (Diptera : Sarcophagidae), at 424 constant temperatures. African Entomology, 14, 357-366.

425 Voss, S.C., CoOK, D.F., Hung, W.-F. \& DAdour, I.R. 2014: Survival and development of the 426 forensically important blow fly, Calliphora varifrons (Diptera: Calliphoridae) at constant 427 temperatures. Forensic Science, Medicine, and Pathology, 10, 314-21.

428 Voss, S.C., Spafford, H. \& DAdOUR, I.R. 2010a: Temperature-dependent development of the 429 parasitoid Tachinaephagus zealandicus on five forensically important carrion fly species. Medical 430 and Veterinary Entomology, 24, 189-98.

431 Voss, S.C., Spafford, H. \& DADOUR, I.R. 2010b: Temperature-dependant development of 432 Nasonia vitripennis on five forensically important carrion fly species. Entomologia 433 Experimentalis et Applicata, 135, 37-47.

434 WiCKHAM, H. 2009: ggplot2: elegant graphics for data analysis. 
435 Wu L-H, WANG C-P, WU W-J. 2012a. Description and Differentiation of the Four Larval Instars 436 of Acanthoscelides macrophthalmus (Coleoptera: Chrysomelidae: Bruchinae). Annals of the 437 Entomological Society of America 105:259-267. DOI: 10.1603/AN11129.

438 Wu L-H, WANG C-P, Wu W-J. 2012b. Description and Differentiation of the Four Larval Instars 439 of Acanthoscelides macrophthalmus (Coleoptera: Chrysomelidae: Bruchinae). Annals of the 440 Entomological Society of America 105:259-267. DOI: 10.1603/AN11129.ZUHA, R.M. \& OMAR, 441 B. 2014: Developmental rate, size, and sexual dimorphism of Megaselia scalaris (Loew) (Diptera: 442 Phoridae): its possible implications in forensic entomology. Parasitology Research, 113, 228544394.

444 Table 1: Summary of development constants for $S$. watsoni for five developmental stages. Sum of 445 effective temperatures $(\mathrm{k})$ and lower developmental threshold $(\mathrm{t})$ shown as means with standard 446 errors (coefficient of determination (R2) and degrees of freedom (Df) and $p$ values are provided).

\begin{tabular}{lcccccc}
\hline Stage & $\begin{array}{c}\text { Temperature } \\
\text { range }\end{array}$ & $\mathbf{R}^{\mathbf{2}}$ & $\mathbf{D f}$ & $\boldsymbol{p}$ value & $\mathbf{k}$ & $\mathbf{t}$ \\
\hline Egg & $15-25$ & 0.8134 & 220 & $2.20 \mathrm{E}-16$ & $929.354 \pm 49.111$ & $11.400 \pm 0.368$ \\
L1 & $15-25$ & 0.9375 & 171 & $2.20 \mathrm{E}-16$ & $233.683 \pm 27.031$ & $15.437 \pm 0.305$ \\
$\mathbf{L 2}$ & $15-25$ & 0.8768 & 206 & $2.20 \mathrm{E}-16$ & $243.945 \pm 45.301$ & $15.689 \pm 0.410$ \\
& & & & & 2602.996 & $9.375 \pm 0.846$ \\
L3 & $15-25$ & 0.8199 & 27 & $1.49 \mathrm{E}-11$ & \pm 297.464 & \\
& & & & & 1207.431 & $12.535 \pm 1.624$ \\
Pupae & $15-21$ & 0.8563 & 10 & $1.61 \mathrm{E}-05$ & \pm 489.288 & \\
\hline
\end{tabular}

447 Table 2: The head widths (in millimeters) of all three larval instars of S. watsoni.

\begin{tabular}{ccccc} 
Instar & max. & min. & mean & stand. dev. \\
\hline L1 & 0.392 & 0.270 & 0.329 & 0.017 \\
L2 & 0.479 & 0.350 & 0.421 & 0.021 \\
L3 & 0.582 & 0.451 & 0.522 & 0.021 \\
\hline
\end{tabular}




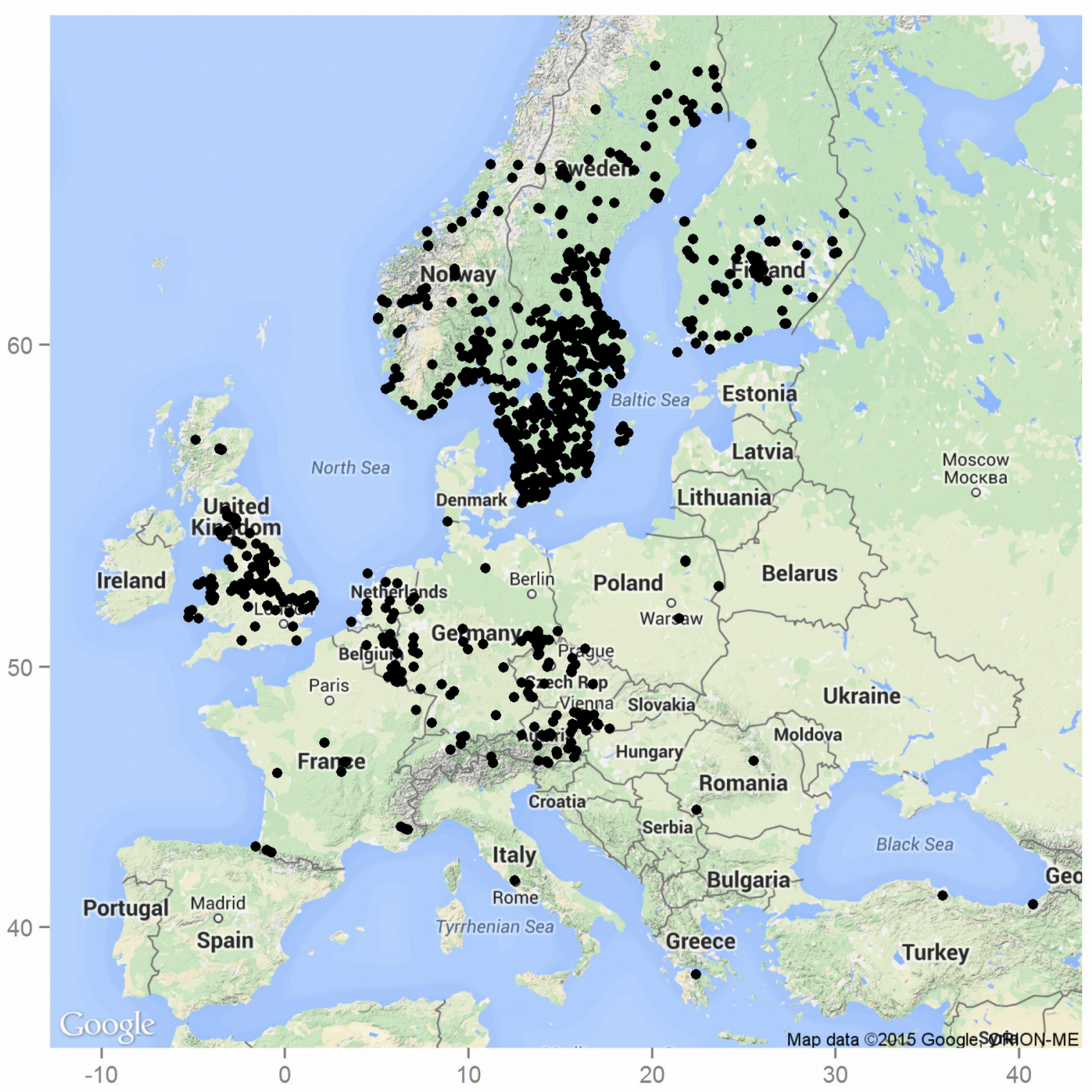

448 Fig. 1: Occurrence of S. watsoni in Europe based on observations and records from the GBIF 449 database (GBIF, 2015). Underlying map generated by package ggmap (Kahle \& Wickham, 450 2013).Map data (C2015 Google. 


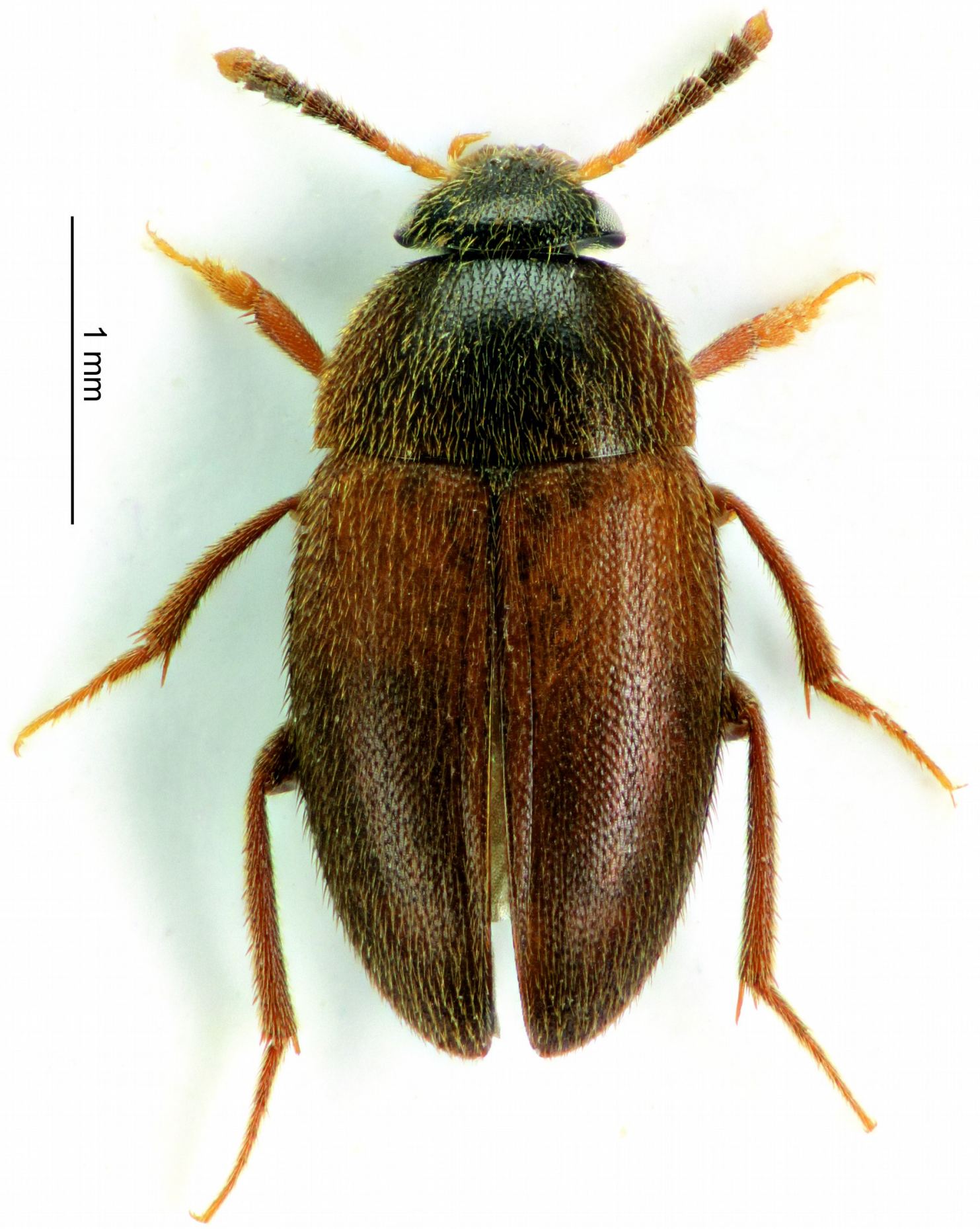

Fig. 2: Habitus of the S. watsoni male from dorsal view. 


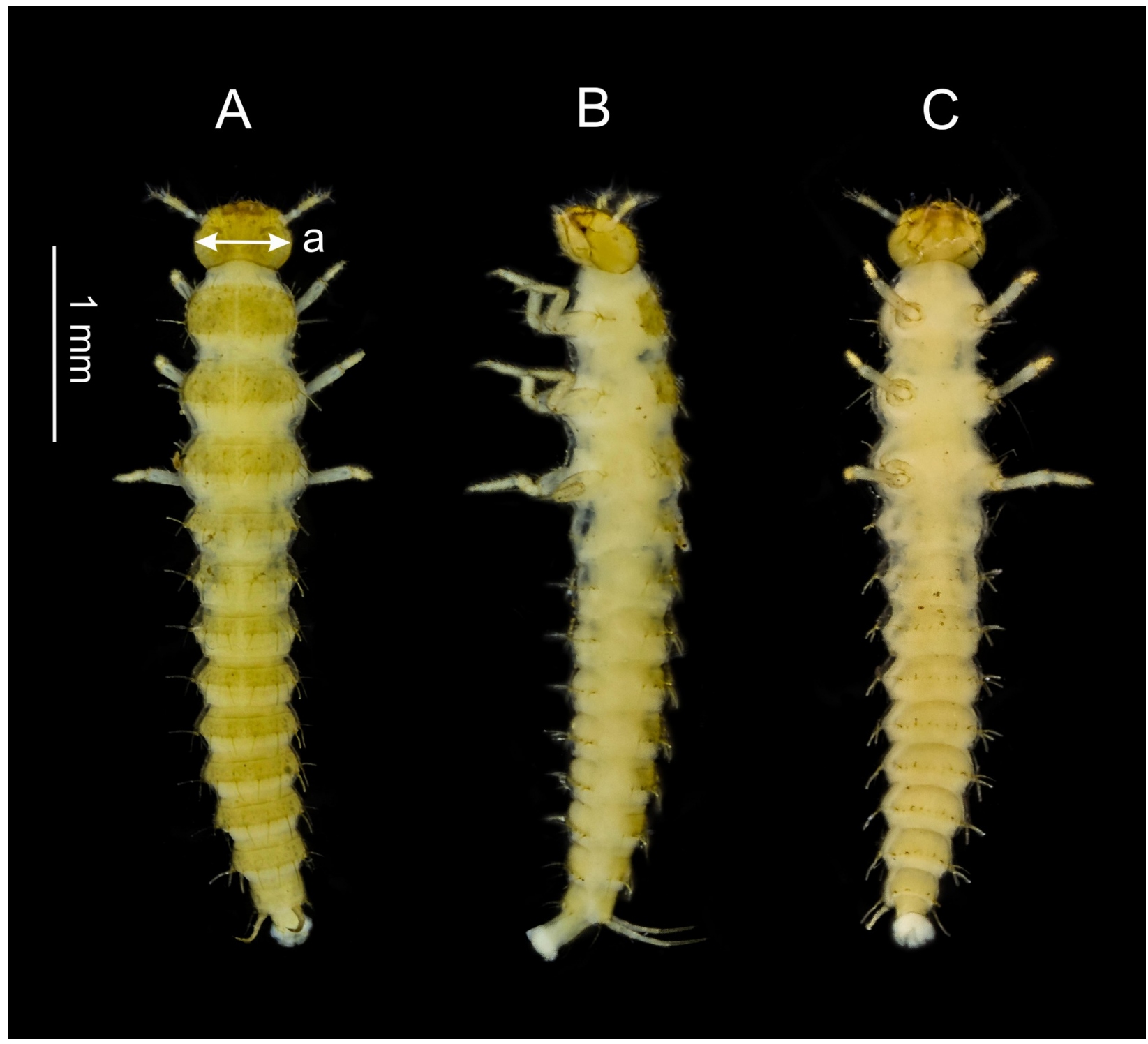

452 Fig.3: Dorsal (A), lateral (B) and ventral (C) side of the third larval instar of S. watsoni. Point 453 where the head width was measured (the widest point of the head capsule) is shown (a). 


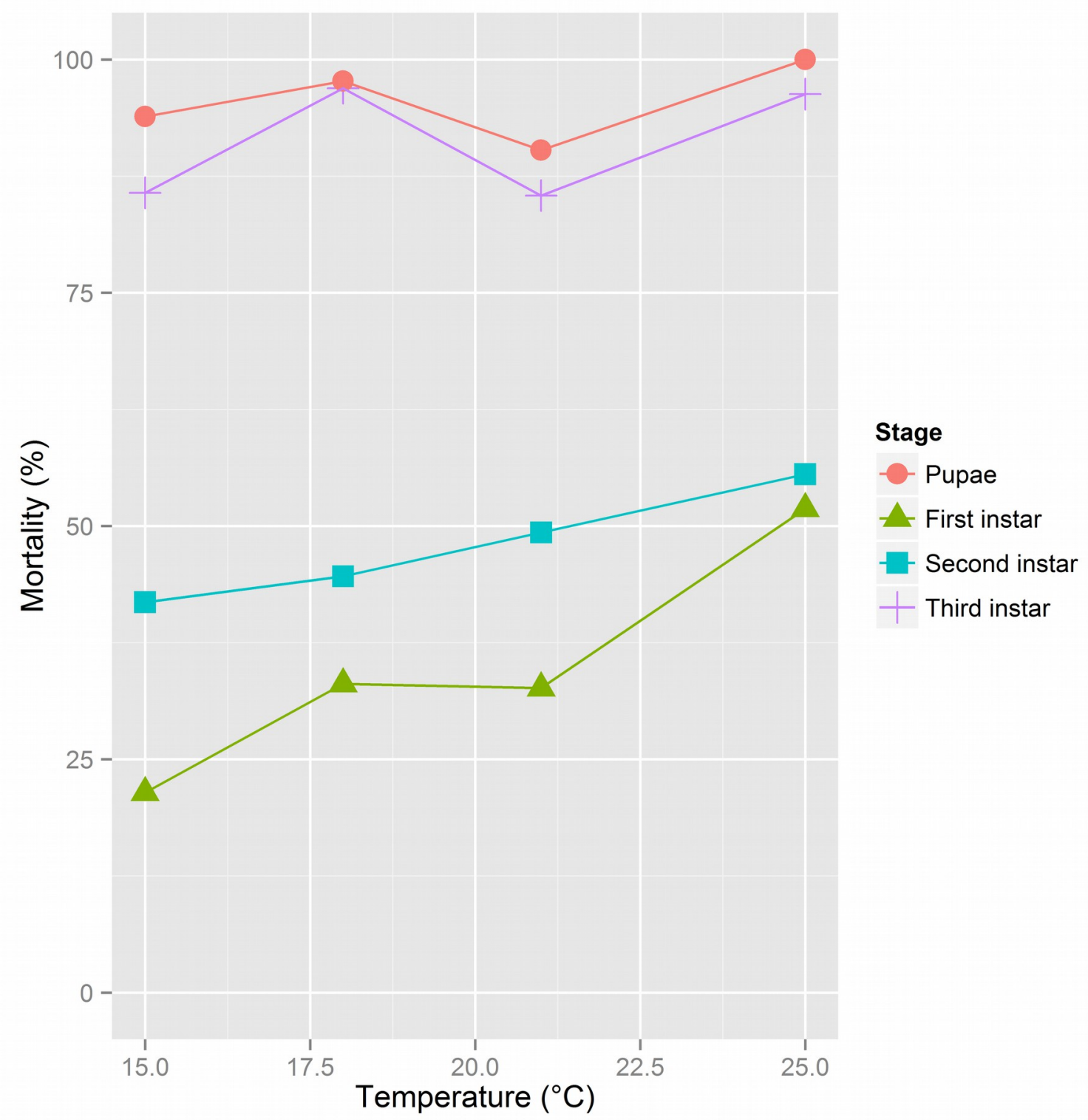

454 Fig. 4: Mortality rates between developmental stages of $S$. watsoni over a range of experimental 455 temperatures, except for 12 and $28^{\circ} \mathrm{C}$, where beetles did not breed successfully. 


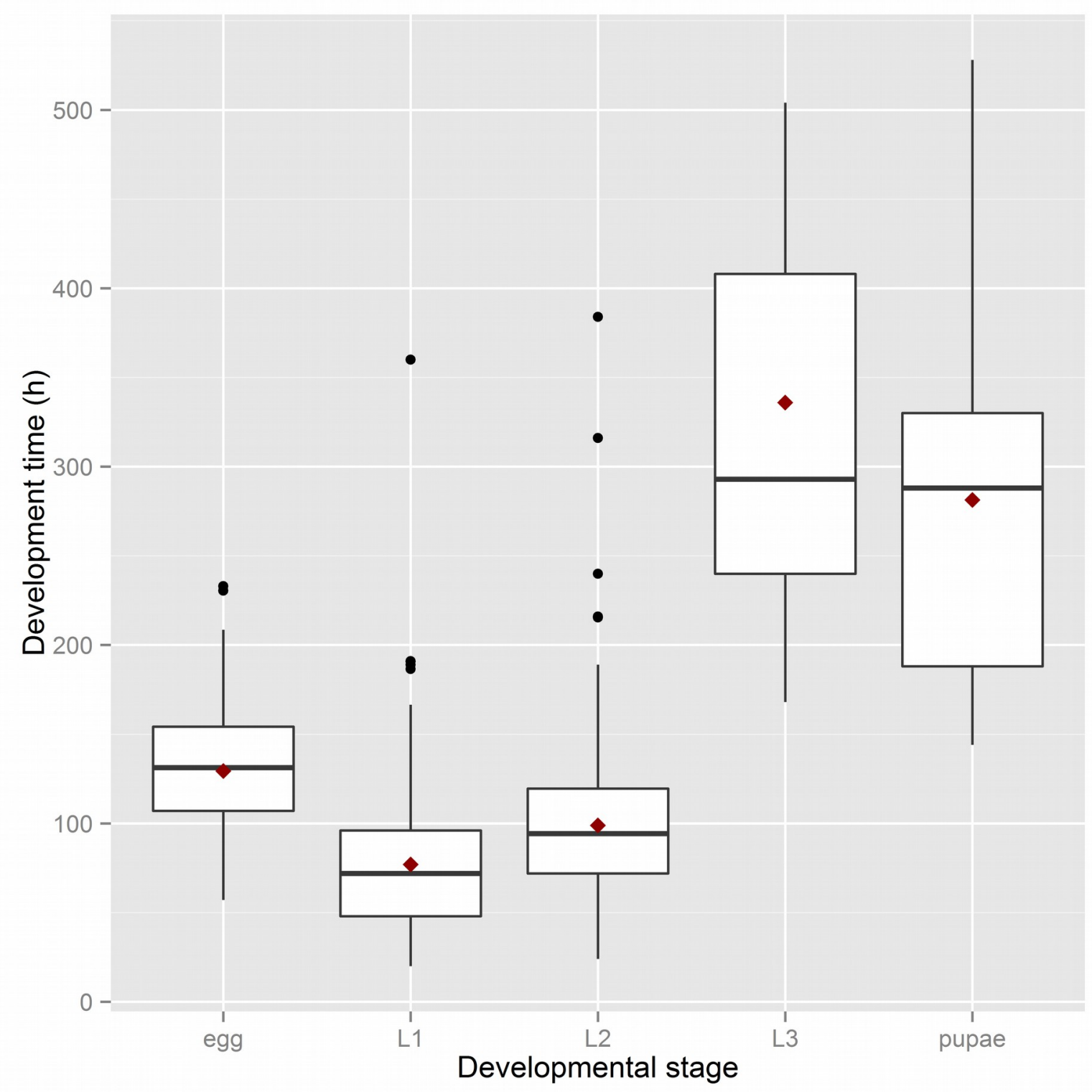

456 Fig. 5: Observed range of development times of $S$. watsoni over four experimental treatments (15, $45718,21,25^{\circ} \mathrm{C}$ ) for each developmental stage (2012 data were excluded for egg and L1). The 458 horizontal lines within the boxes indicate median values. The upper and lower boxes indicate the 45975 th and 25th percentiles, respectively. Whiskers indicate the values with the 1.5 interquartile 460 ranges. Small, black dots are outliers. Small red dots are the mean values of development time. 


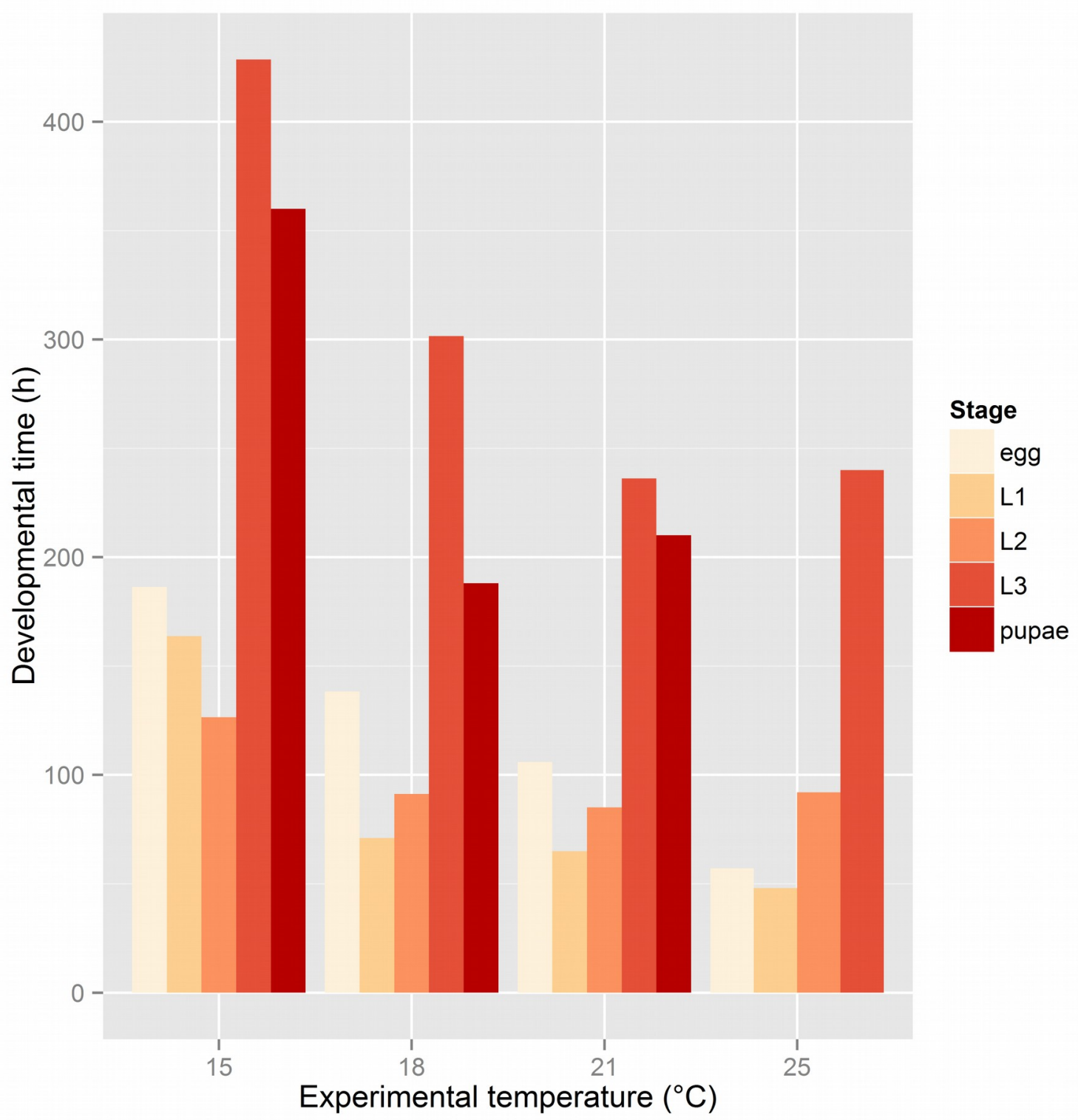

461 Fig. 6: Bar plot of mean development time (in hours) of all observed stages (2012 data were 462 excluded for egg and L1) of $S$. watsoni over a range of experimental temperatures, except for 12 463 and $28^{\circ} \mathrm{C}$, where beetles did not breed successfully. 

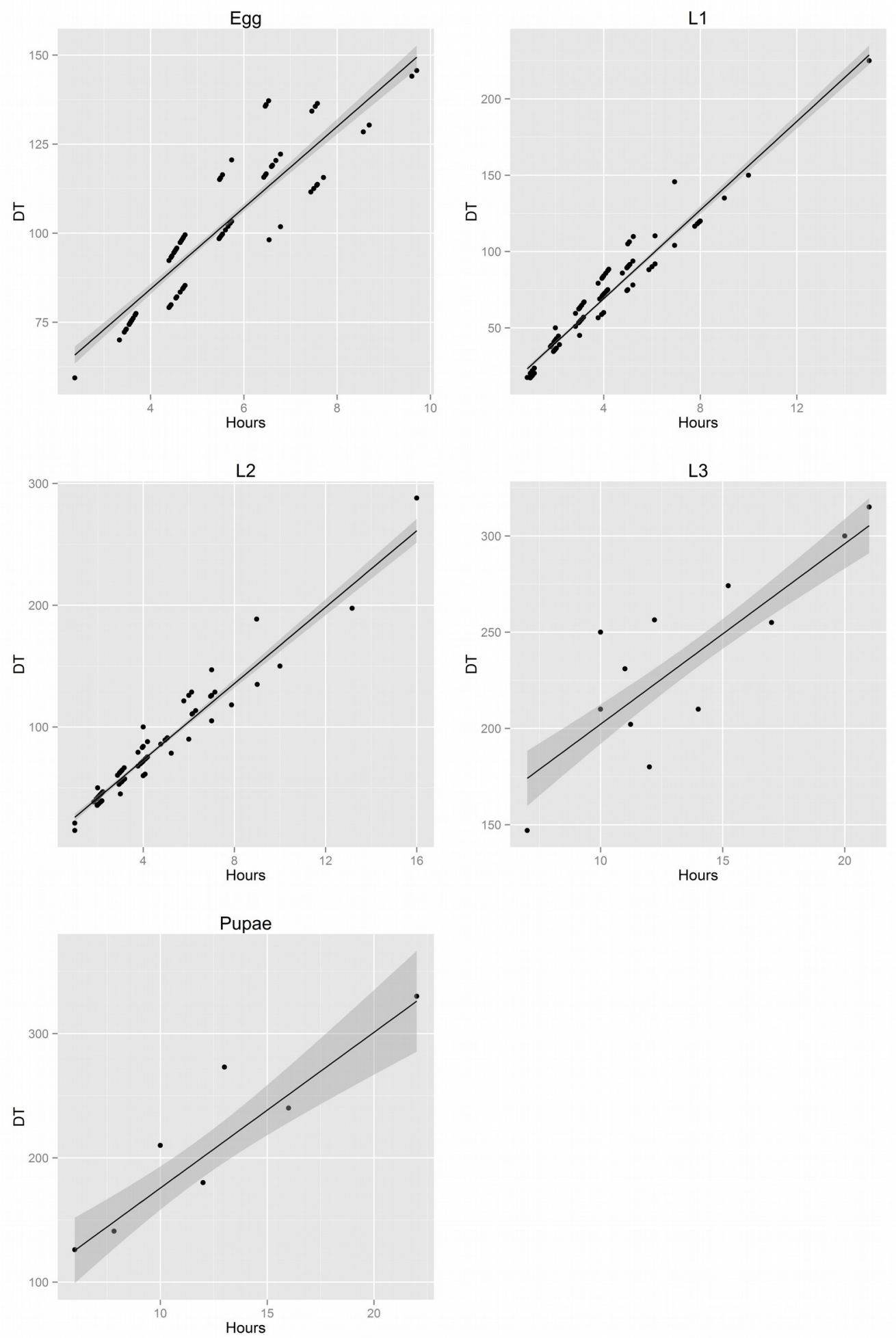

464 Fig. 7: Major axis regression for all stages of development in S. watsoni. Black line shows 465 median and gray area around is standard error. DT is the time in days to reach the stage 466 multiplied by the constant rearing temperature. 2012 data were excluded for egg and L1. 


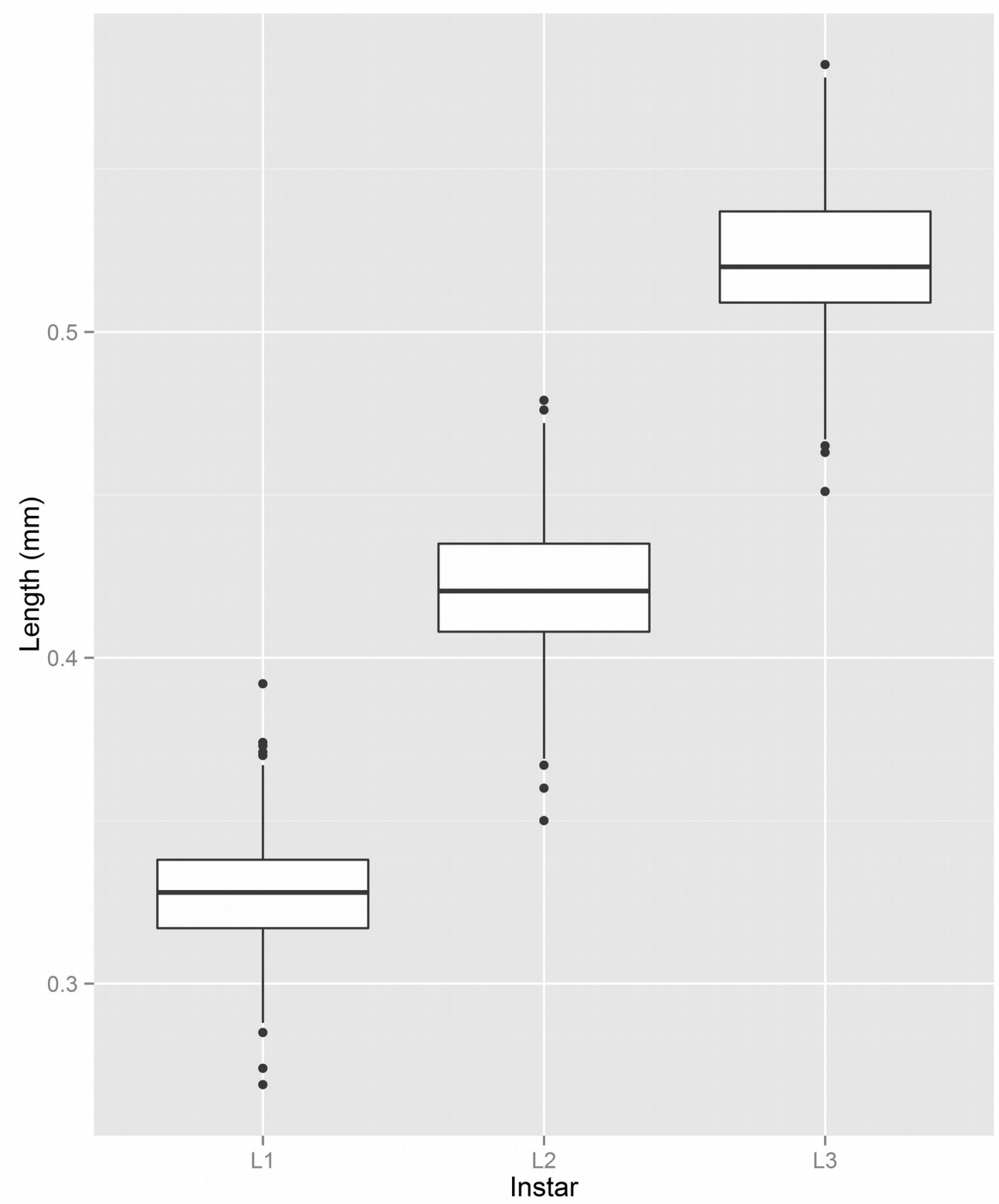

467 Fig. 8: Box plot graph of lengths of all three instars (L1, L2 and L3) of the S. watsoni larvae. The 468 horizontal lines within the boxes indicate median values. The upper and lower boxes indicate the 46975 th and 25th percentiles, respectively. Whiskers indicate the values with the 1.5 interquartile 470 ranges. Small, black dots are outliers. 